\title{
The GOLIATH Project: Towards an Internationally Harmonised Approach for Testing Metabolism Disrupting Compounds
}

Juliette Legler ${ }^{1}{ }^{*}$, Daniel Zalko ${ }^{2} \mathbb{D}$, Fabien Jourdan ${ }^{2} \mathbb{D}$, Miriam Jacobs ${ }^{3}$, Bernard Fromenty ${ }^{4}$, Patrick Balaguer ${ }^{5}$ D, William Bourguet ${ }^{6}$, Vesna Munic Kos ${ }^{7}$, Angel Nadal ${ }^{8} \mathbb{D}$, Claire Beausoleil $^{9}$, Susana Cristobal ${ }^{10}\left(\mathbb{D}\right.$, Sylvie Remy ${ }^{11}(\mathbb{D})$, Sibylle Ermler ${ }^{12}\left(\mathbb{D}\right.$, Luigi Margiotta-Casaluci ${ }^{12}(\mathbb{D})$, Julian L. Griffin ${ }^{13}$, Bruce Blumberg ${ }^{14}$, Christophe Chesné ${ }^{15} \mathbb{D}$, Sebastian Hoffmann ${ }^{16}(\mathbb{D})$, Patrik L. Andersson ${ }^{17}$, Jorke H. Kamstra ${ }^{1}(\mathbb{D})$ and on behalf of the GOLIATH Consortium

1 Institute for Risk Assessment Sciences, Department of Population Health Sciences, Faculty of Veterinary Medicine, Utrecht University, 3508 TD Utrecht, The Netherlands; j.h.kamstra@uu.nl

2 INRAE Toxalim (Research Centre in Food Toxicology), Metabolism and Xenobiotics (MeX) Team, Université de Toulouse, INRAE, ENVT, INP-Purpan, UPS, 31027 Toulouse, France; daniel.zalko@inrae.fr (D.Z.); fabien.jourdan@inrae.fr (F.J.)

3 Centre for Radiation, Chemical and Environmental Hazards, Public Health England, Chilton OXON. OX11 0RQ, UK; Miriam.Jacobs@phe.gov.uk

4 Institut NUMECAN (Nutrition Metabolisms and Cancer) INSERM UMR_A 1341, UMR_S 1241, Université de Rennes, F-35000 Rennes, France; bernard.fromenty@inserm.fr

5 Institut de Recherche en Cancérologie de Montpellier (IRCM), INSERM U1194, ICM, Université de Montpellier, 34298 Montpellier, France; patrick.balaguer@inserm.fr

6 Center for Structural Biochemistry (CBS), INSERM, CNRS, Université de Montpellier, 34090 Montpellier, France; william.bourguet@cbs.cnrs.fr

7 Department of Physiology and Pharmacology, Karolinska Institutet, 17177 Stockholm, Sweden; vesna.munic.kos@ki.se

8 IDiBE and CIBERDEM, Universitas Miguel Hernandez, 03202 Elche (Alicante), Spain; nadal@umh.es

9 ANSES, Direction de l'Evaluation des Risques, Agence Nationale de Sécurité Sanitaire de l'Alimentation, de l'Environnement et du Travail, 14 rue Pierre et Marie Curie, 94701 Maisons-Alfort CEDEX, France; claire.beausoleil@anses.fr

10 Department of Biomedical and Clinical Sciences (BKV), Cell Biology, Medical Faculty, Linköping University, SE-581 85 Linköping, Sweden; susana.cristobal@liu.se

11 Sustainable Health, Flemish Institute for Technological Research, VITO, 2400 Mol, Belgium; sylvie.remy@vito.be

12 Department of Life Sciences, College of Health and Life Sciences, Brunel University London, Uxbridge UB8 3PH, UK; Sibylle.Ermler@brunel.ac.uk (S.E.); Luigi.Margiotta-Casaluci@brunel.ac.uk (L.M.-C.)

13 Section of Biomolecular Medicine, Division of Systems Medicine, Department of Metabolism, Digestion and Reproduction, Imperial College London, South Kensington, London SW7 2AZ, UK; jlg30@ic.ac.uk

14 Department of Developmental and Cell Biology, University of California Irvine, 2011 BioSci 3, University of California, Irvine, CA 92697-2300, USA; blumberg@uci.edu

15 Biopredic International, Parc d'Activité de la Bretèche Bâtiment A4, 35760 Saint Grégoire, France; christophe.chesne@biopredic.com

16 Seh Consulting + Services, 33106 Paderborn, Germany; sebastian.hoffmann@seh-cs.com

17 Chemistry Department, Umeå University, SE-90187 Umea, Sweden; patrik.andersson@umu.se

* Correspondence: j.legler@uu.nl; Tel.: +31-30-253-5217

Received: 1 April 2020; Accepted: 8 May 2020; Published: 14 May 2020

Abstract: The purpose of this project report is to introduce the European "GOLIATH" project, a new research project which addresses one of the most urgent regulatory needs in the testing of endocrine-disrupting chemicals (EDCs), namely the lack of methods for testing EDCs that disrupt metabolism and metabolic functions. These chemicals collectively referred to as "metabolism 
disrupting compounds" (MDCs) are natural and anthropogenic chemicals that can promote metabolic changes that can ultimately result in obesity, diabetes, and/or fatty liver in humans. This project report introduces the main approaches of the project and provides a focused review of the evidence of metabolic disruption for selected EDCs. GOLIATH will generate the world's first integrated approach to testing and assessment (IATA) specifically tailored to MDCs. GOLIATH will focus on the main cellular targets of metabolic disruption-hepatocytes, pancreatic endocrine cells, myocytes and adipocytes-and using an adverse outcome pathway (AOP) framework will provide key information on MDC-related mode of action by incorporating multi-omic analyses and translating results from in silico, in vitro, and in vivo models and assays to adverse metabolic health outcomes in humans at real-life exposures. Given the importance of international acceptance of the developed test methods for regulatory use, GOLIATH will link with ongoing initiatives of the Organisation for Economic Development (OECD) for test method (pre-)validation, IATA, and AOP development.

Keywords: risk assessment; chemicals; endocrine; obesity; diabetes

\section{Introduction}

The incidence of obesity and metabolic disorders such as diabetes and non-alcoholic fatty liver disease (NAFLD) has reached "Goliathan" proportions. In Europe alone, more than 50 million people suffer from one or a combination of these disorders [1,2]. The worldwide increase in metabolic disorders cannot be explained by lifestyle and genetic factors alone; the role of environmental factors in these disorders has been increasingly acknowledged [3]. Exposure to endocrine-disrupting chemicals (EDCs) that disrupt metabolic functions-chemicals collectively referred to as "metabolism disrupting chemicals" (MDCs) - is an environmental risk factor that urgently requires more attention. MDCs are natural and anthropogenic chemicals that can promote metabolic changes, which can ultimately result in obesity, diabetes, and/or fatty liver in humans [4]. Given the important role these metabolic alterations can play in the global epidemics of metabolic disorders, international chemical regulations must pay due attention to the identification of MDCs and the assessment of the risk associated with exposure.

Within European chemicals regulations, criteria to identify EDCs have been recently proposed that require information on a chemical's endocrine mode of action (MoA) and related adverse effects relevant for human health [5]. This involves the screening and testing of EDCs according to the EU Test Methods Regulation [6], which mainly incorporates internationally accepted test methods developed under the Organisation for Economic Cooperation and Development (OECD) [7]. The current validated and standardized test methods to identify EDCs are principally focused on well-studied endocrine pathways in the estrogen, androgen, and thyroid systems. However, there are no suitable in vivo or in vitro tests for regulatory purposes that identify the potential metabolic and metabolism disrupting effects of chemicals. The need for these tests has been internationally recognized (e.g., [8-11]), as, without them, comprehensive hazard and risk assessment of chemicals for potential metabolic disrupting activity is virtually impossible.

In January 2019, the five-year European research project "Beating Goliath: Generation of Novel, Integrated and Internationally Harmonized Approaches for Testing Metabolism Disrupting Chemicals" (GOLIATH) started, with a consortium comprised of world-leading experts in endocrinology and molecular biology, endocrine disruption, toxicology, epidemiology, bioinformatics, test method development, (pre-)validation, and chemical regulation. The overall aim of the GOLIATH project is to improve hazard assessment of MDCs by generating novel, optimized, integrated, and internationally harmonized approaches for testing metabolic disruption. The GOLIATH project spans the entire spectrum of testing, from in silico predictive modeling and high throughput screening, to the development of robust ready-to-use in vitro assays and improving the utility of current in vivo testing 
guidelines. By incorporating novel omics technologies, and translating in vitro and in vivo assays to human health effects, GOLIATH will generate new integrated approaches to testing and assessment for MDCs, incorporating mainly in vitro test methods, as well as providing novel insights in the mechanisms by which MDCs disrupt metabolic pathways and induce adverse effects on human health. GOLIATH is one of eight projects awarded funding within EURION, the "European cluster to improve identification of endocrine disruptors" (see also https:/eurion-cluster.eu/).

This project report has the following main objectives (1) to introduce the background to the project, i.e., metabolic disorders and the major classes of MDCs that will be studied in the GOLIATH; (2) to describe the approaches developed in the GOLIATH project; (3) to provide a brief state-of-the-art review of the approaches that have been used up to now to assesses metabolic disrupting activity and related adverse effects of EDCs. A final objective of this project report is to raise awareness of the scientific community of the forthcoming data that will be generated in this project, ensuring that the data will be open access, in line with the "Findable, Accessible, Interoperable, Reusable (FAIR) initiative [12].

\section{Metabolic Disorders}

GOLIATH focuses on developing test methods that will contribute to the assessment of the role of MDCs in obesity and metabolic disorders including insulin resistance (IR), type 2 diabetes (T2D), and NAFLD (Figure 1). The WHO defines obesity as "abnormal or excessive fat accumulation that may impair health," and diabetes as a "chronic disease caused by inherited and/or acquired deficiency in production of insulin by the pancreas, or by the ineffectiveness of the insulin produced" [1]. NAFLD is a disease "characterized by excessive hepatic fat accumulation, defined by the presence of steatosis in $>5 \%$ of hepatocytes" [13]. Maintenance of plasma glucose levels within the physiological range is based on a negative feedback system between insulin production and release by pancreatic $\beta$-cells and insulin response by insulin-sensitive tissues, mainly liver, adipocytes, and skeletal muscle. IR is a hallmark of obesity, NAFLD, and a predecessor of T2D, and can develop in response to environmental factors, such as aging, obesity, and exposure to MDCs. In susceptible individuals, environmentally-induced peripheral IR raises blood glucose levels, which, in turn, stimulate insulin secretion by pancreatic $\beta$-cells. The resulting hyperinsulinemia will cause further IR, which may generate a vicious circle that leads to $\beta$-cell failure, reduced $\beta$-cell mass, and, ultimately, T2D (Figure 1).

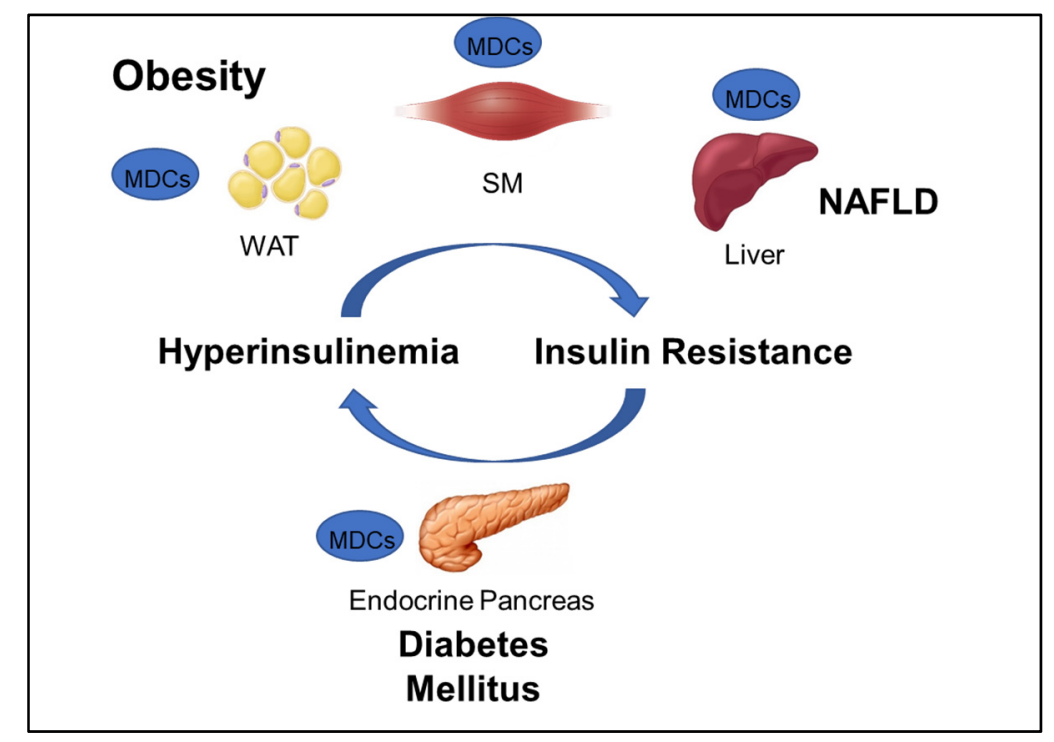

Figure 1. Interconnection between obesity and major metabolic disorders and the corresponding tissues that can be targeted by metabolic disrupting chemicals (MDCs). NAFLD: non-alcoholic fatty liver disease; WAT: white adipose tissue, SM: skeletal muscle. 


\section{Metabolic Disrupting Chemicals}

New discoveries made in the last 15 years have provided solid evidence that MDCs cause IR in peripheral tissue and alter $\beta$-cell mass and function $[4,14,15]$. Furthermore, MDCs can act as "obesogens," inducing adipogenesis as well as hyperplasia and hypertrophy of adipocytes in white adipose tissue (WAT) [4]. Evidence suggesting the effects of MDCs on other forms of adipocytes, such as thermogenic beige/brite and brown fat cells, is emerging but is still an understudied area of research. MDCs can also directly affect the liver, promoting IR and de novo lipogenesis, thus favoring fatty liver disease development and progression [4]. Development of fatty liver is a major health issue since this lesion can progress to non-alcoholic steatohepatitis (NASH) and then to severe liver diseases including cirrhosis and hepatocellular carcinoma [2]. Studies in vivo indicate that skeletal muscle might be a target tissue of MDCs as well, although evidence of a direct effect on isolated cells is still very scarce. MDC exposure is thus a risk factor for obesity, and IR, and increases the risk of developing T2D, NAFLD, and other metabolism-related diseases.

The list of chemicals implicated in metabolic disorders is growing and includes bisphenols, pesticides, phthalates, metals, and perfluorinated compounds [4]. Recent literature reviews are available that synthesize the reported metabolism disrupting effects of these chemicals in laboratory studies $[4,15,16]$. For example, bisphenol A (BPA) has been shown to directly stimulate $\beta$-cells and cause primary hyperinsulinemia after amplification of glucose-stimulated insulin secretion in rodents, leading to IR in skeletal muscle and liver [17]. BPA is also known to induce steatosis in human hepatocytes [18] and has obesogenic properties, whereas developmental BPA exposures in rodents are associated with increased adiposity [19]. A brief overview of the initial set of MDCs that will be tested in GOLIATH is shown in Table 1. This initial set of model test chemicals was selected because they have a wide range of mechanisms of action $(\mathrm{MoA})$, and there is existing data from animal and/or human studies that indicate metabolism disrupting effects following exposure. In addition, all of these six chemicals have been detected in humans in biomonitoring studies. A summary of human epidemiological studies linking (early life) exposure and metabolic disorders in these six chemicals from the literature are shown in Table S1. An overview of the available human biomonitoring data for four of these chemicals in Belgian cohorts is given in Table S2, while for tributyltin (TBT) and diphenyl phosphate (DHPH, a metabolite of triphenyl phosphate (TPP)), an overview of international biomonitoring data is provided in Table S3.

Table 1. Classes of MDCs and the initial set of model compounds that will be tested in GOLIATH, putative human nuclear receptor (NR)-mediated mechanism of action (MoA) and weight of evidence from animal and human studies as well as the availability of data on human exposure from biomonitoring studies.

\begin{tabular}{|c|c|c|c|c|c|c|}
\hline Chemical & Identifiers (CAS; ChEBI; Inchikey) & Structure & MoA & Animal & Human & Biomon. Data \\
\hline Bisphenol A (BPA) & $\begin{array}{c}\text { 80-05-7; 33216; } \\
\text { IISBACLAFKSPIT-UHFFFAOYSA-N }\end{array}$ & & $\begin{array}{c}\text { hER } \alpha \text { hER } \beta \text { hPXR } \\
\text { hCAR }\end{array}$ & ++ & + & + \\
\hline $\begin{array}{l}\text { Tributyltin Chloride } \\
\text { (TBT) }\end{array}$ & $\begin{array}{c}\text { 1461-22-9; 79734; } \\
\text { GCTFWCDSFPMHHS-UHFFFAOYSA-M }\end{array}$ & & $\begin{array}{c}\text { hRXR } \\
\text { hPPAR } \gamma\end{array}$ & +++ & - & - \\
\hline $\begin{array}{l}\text { Perfluorooctanoic acid } \\
\text { (PFOA) }\end{array}$ & $\begin{array}{c}\text { 3825-26-1; 35549; } \\
\text { SNGREZUHAYWORS-UHFFFAOYSA-N }\end{array}$ & & $\begin{array}{c}\text { hPXR } \\
\text { hPPAR } \gamma\end{array}$ & ++ & + & ++ \\
\hline $\begin{array}{l}\text { Triphenylphosphate } \\
\text { (TPP) }\end{array}$ & $\begin{array}{c}\text { 115-86-6; 35033; } \\
\text { XZZNDPSIHUTMOC-UHFFFAOYSA-N }\end{array}$ & & $\begin{array}{l}\text { hER } \alpha \text { hER } \beta \text { hPXR } \\
\text { hCAR hPPAR } \gamma\end{array}$ & ++ & \pm & + \\
\hline
\end{tabular}


Table 1. Cont.

\begin{tabular}{ccccc}
\hline Chemical & Identifiers (CAS; ChEBI; Inchikey) & Structure & MoA & Animal Human Biomon. Data \\
\hline $\begin{array}{c}\text { Dichlorodiphenyldic } \\
\text { hloroethylene } \\
\text { (pp'-DDE) }\end{array}$ & $\begin{array}{c}72-55-9 ; 16598 ; \\
\text { UCNVFOCBFJOQAL-UHFFFAOYSA-N }\end{array}$ & $\begin{array}{c}\text { 3380-34-5; } 164200 ; \\
\text { Triclosan (TCS) } \\
\text { XEFQLINVKFYRCS-UHFFFAOYSA-N }\end{array}$ & hPXRhPPAR $\gamma$ & ++ \\
\hline
\end{tabular}

Weight of evidence key: - = absence of evidence; \pm = equivocal evidence; $+=$ some evidence; $++=$ moderate evidence; $+++=$ strong evidence.

\section{Test Methods in GOLIATH to Determine Metabolism Disrupting Activity}

The integrated structure of GOLIATH is straightforward (Figure 2): using an Adverse Outcome Pathway (AOP) framework, we will develop test methods that cover the pathways from the molecular initiating event (MIE) to a key event in cells and tissues, to the adverse metabolic outcome in humans. To this end, for MIE testing, we will develop in silico predictive models based on MIEs, molecular dynamics to predict human nuclear receptor (NR) binding; high throughput screening (HTS) assays to confirm NR binding and transactivation. Specific in vitro models will be developed using key target tissues (adipose, liver, endocrine pancreas, skeletal muscle) to model key cellular events that may lead to adverse outcomes. We will further develop an alternative zebrafish assay for metabolic disruption and use this assay, together with data from existing in vivo rodent assays to predict adverse outcomes in humans. We will work closely with epidemiologists to ensure the translation of lower and higher-tiered methods to the human situation. In the following section, we will briefly introduce each of these models, as well as review relevant literature available on testing MDCs in these models.

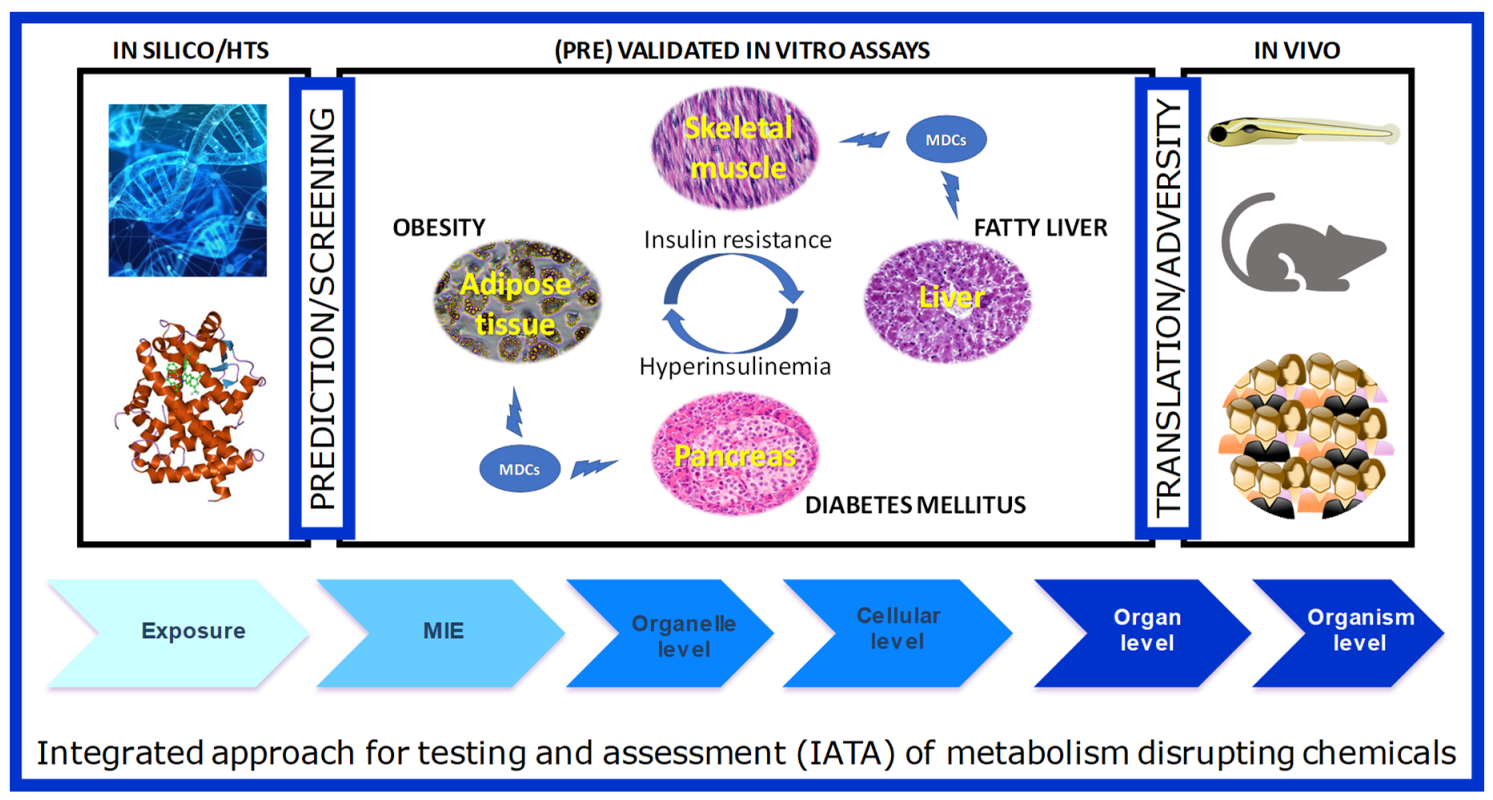

Figure 2. The schematic framework of test method development in the GOLIATH project in an Adverse Outcome Framework. Ultimately, the tests developed and pre-validated within GOLIATH will be integrated to form an IATA for metabolism disrupting chemicals.

\subsection{Test Methods to Determine MIEs}

\subsubsection{In Silico Predictive Models}

In the first three years of the project, GOLIATH will develop and apply alternative methods, carried out solely in a computer-based interface to obtain information on the hazard of a substance. The most prominent in silico approaches for the generation of predictive data are (Quantitative) 
Structure-Activity Relationships ((Q)SARs), category formation, and read-across methods. In silico screening methods have been proposed for numerous endpoints (e.g., profilers for DNA binding in QSAR Toolbox [20]) and their use has been encouraged from regulatory bodies to support decision making (e.g., REACH legislation (2007)) with guidance on validation principles [21]. The main drive and limitation for the development of reliable computational approaches is high-quality data. These data together with the applied methodology define the applicability domain of the model which is a key concept of in silico modeling, i.e., the defined chemical space for which a computational method can reliably provide predictions.

As reviewed in Schneider et al. [22], the majority of in silico studies for identifying potential MDCs and studying NR mediated interactions involved in metabolic disorder apply (Q)SAR models. Further, physiologically-based toxicokinetic/pharmacokinetic (PBTK/PBPK) models have been used for prediction of absorption, distribution, metabolism, and excretion (ADME) processes and facilitation of quantitative in vitro-in vivo extrapolation (QIVIVE). Notable examples of MDC specific PBTK models have been suggested for BPA [23], and TPP [24]. (Q)SAR models have been developed for the NRs involved in metabolism disrupting effects, i.e., PPAR $\alpha, \operatorname{PPAR} \gamma, \mathrm{PXR}, \mathrm{CAR}, \mathrm{LXR} \alpha, \mathrm{LXR} \beta, \mathrm{FXR}$, for endpoints such as median effective concentration (EC50), and inhibitory affinity constant $\left(\mathrm{K}_{\mathrm{i}}\right)$ for defined applicability domains (Table S4). These include local models for CAR activity with a limited set of chemicals (e.g., [25]) to large initiatives using Tox21 HTS data for FXR [26] and methodologies spanning from combining molecular docking and pharmacophore filtering to identify agonists of PPAR $\gamma$ [27] to classification models identifying chemicals activating and antagonizing PXR [28].

The growing number of 3D crystal structures of protein targets in complex with ligands provides a wealth of structural information that can be used to predict their interactions with EDCs using docking and scoring procedures. GOLIATH uses and further develops the online prediction tool called EDMon (Endocrine Disruptor Monitoring) dedicated to ligand screening of nuclear receptors which relies upon known crystal structures or models and the availability of large experimental ligand affinity datasets. The server is currently available (http://edmon.cbs.cnrs.fr) to screen for estrogen receptors $(E R \alpha / \beta)$ and the peroxisome proliferator-activated receptor $\gamma(\operatorname{PPAR} \gamma)$. By uploading compound information in an appropriate (mol2) format, the user can get predictions of the binding modes and affinities using a rescoring approach based on machine learning [29]. Within GOLIATH, this tool will be extended to include NRs identified as key MIEs in metabolism disruption.

\subsubsection{NR Screening}

The GOLIATH project will use reporter cell lines stably expressing the ligand-binding domain (LBD) of human PPAR $\alpha, \operatorname{PPAR} \gamma, \mathrm{LXR} \alpha, \mathrm{LXR} \beta, \mathrm{PXR}$, or CAR fused to the yeast GAL4 DNA binding domain (DBD) and the luciferase under the control of five GAL4 responsive elements to screen the initial set of GOLIATH compounds (Table 1) as well as a large number of environmental compounds. These reporter cell lines were generated by a two-step transfection procedure [30]. First, a stable cell line, HG5LN, expressing only the reporter gene was developed. These cells were then transfected with the different receptor genes. These six nuclear receptors reporter cell lines are powerful tools to characterize the nuclear receptor activity of EDCs in a standardized, high-throughput screening technique. In addition, the HG5LN parental cell line is used as a negative control. These cellular assays have previously shown that BPA activates PXR but no PPAR $\gamma$ while TBBPA activates both receptors [31,32]. In the first two years of the project, a library of hundreds of candidate MDCs will be screened with these reporter gene assays to identify mechanisms of action. In addition, up to two of these reporter gene assays will be further developed and optimized as candidate assays to go forward to pre-validation.

\subsubsection{Bioactive Thermal Protein Profiling (bTPP)}

GOLIATH will apply the bioactive thermal proteome profiling (bTPP) methodology to provide a comprehensive assessment of cellular proteins that interact with MDCs. This assessment 
includes the identification of the protein targets, determination of the differential affinity among targets, and prediction of a network of molecular pathways and the mechanisms of actions [33]. The evaluation of the parameters that define the target engagement has been traditionally performed in single-parameter assays until the development of the cellular thermal shift assay (CETSA) [34]. This method was first used to measure the increase of thermal stability to the unfolding of proteins that were interacting with other compounds. Thermal proteome profiling is a subsequent development of the CETSA that uses quantitative mass spectrometry to identify and quantity the folded and unfolded proteins from a proteome after a thermal shift assay. This method has been successfully applied to study drug targets and off-targets [35,36], as well as for deciphering drug-target interaction $[37,38]$ and defining specific mechanisms of action in very complex samples [39]. In the GOLIATH project, we will spend the first three to four years developing a modified method of thermal protein profiling, called bTPP [33] to identify MIEs in cells and zebrafish.

\subsection{Test Methods to Determine Key Events, i.e., In Vitro Models of Metabolic Disruption}

As mentioned above, in vitro models of metabolic disruption will be developed for the liver, pancreas, skeletal muscle, and adipose tissue, for which the methods to be developed are outlined below. We acknowledge that metabolism involves a complex interplay between multiple organs and tissues in the body, including inter alia the brain and the gut, but decided to focus on liver, pancreas, skeletal muscle, and adipose tissue, which we consider as key organs for metabolic disruption. However, we will work together with other projects in the EURION cluster that investigate those additional organs and tissues.'

\subsubsection{Liver}

Investigations regarding MDC metabolism and metabolic disruption in hepatocytes are carried out in HPR116 cells (Biopredic International, Saint-Grégoire, France), which are cryopreserved differentiated HepaRG cells. The HepaRG cell line is derived from a liver tumor of a female patient suffering from hepatocarcinoma [40]. Notably, differentiated HepaRG cells express xenobiotic-metabolizing enzyme (XME) activities close to those measured in primary human hepatocyte cultures [41,42]. Furthermore, these cells also express several key transcription factors regulating XME expression such as AhR, PXR, CAR, and PPARs [42-44]. Of note, the differentiated HepaRG cells present mitochondrial function close to primary human hepatocytes $[45,46]$. More generally, recent investigations reported that the deep proteome of HepaRG cells is overall similar to that of primary human hepatocytes [47].

\section{Metabolism in HPR116 Cells}

The metabolism of xenobiotics and endogenous metabolism are closely intertwined as they rely on a common pool of enzymes, regulated by specific NRs. For this reason, the modulation (induction, inhibition) of XME activities by xenobiotics can have a major impact not only on their own metabolic fate but also on endogenous anabolic and catabolic metabolic pathways. In the case of MDCs, these are potential mechanisms of action that need to be better investigated. In GOLIATH, the functional metabolic capabilities of HPR116 cells will be assessed using a battery of phase I and phase II XME functional activities measurement assays, with both short term and long term exposure. For phase I reactions, these include the characterization of cytochrome P450 (CYP) activities using $\left[{ }^{14} \mathrm{C}\right]$-labeled testosterone. The formation of the different metabolites of testosterone through CYP450 oxidations is regio-selective in humans [48], thus allowing to estimate the functional activities of major CYP isoforms based on the quantification of specific testosterone metabolites. For phase II reactions, the characterization of UDP-glucuronyl transferases (UGTs) and sulfotransferases (SULTs) activities will be achieved using probe substrates such as 4-methyl-umbelliferone and 7-hydroxycoumarin.

In addition, extensive work will be carried out in the first two years of GOLIATH to expand the chemical applicability domain of the "CYP induction assay." This assay was originally validated with pharmaceuticals within the EURL ECVAM Multi-study Validation Trial [49] and was recently 
summarized and published by Bernasconi et al. [50]. The CYP induction assay aims at assessing the potential of xenobiotics to induce key CYP activities in vitro (CYP1A, CYP2B, and CYP3A). CYP1A2, CYP2B6, and CYP3A4 are globally accepted as biomarkers of CYP induction in the regulatory guidelines of pharmaceutical agencies [50]. CYP induction processes rely on the binding/activation of specific transcription factors and NRs such as AhR, CAR, and PXR which can constitute MIEs involved in the onset of putative adverse effects of MDCs. In GOLIATH, the objective is to support the validation (Bernasconi et al.) by extending the chemical applicability domain of the CYP induction assay, beyond the validation reference chemical set of pharmaceuticals, to achieve a better prediction of the capability of industrial chemicals and pesticides to induce human CYP activities. Using the existing standard operating procedure (SOP) detailed in an OECD draft test guideline [51], we will use HPR116 cells exposed to selected test chemicals for $48 \mathrm{~h}$ to determine key CYP activities following the use of a cocktail of specific probe substrates (phenacetin, bupropion, midazolam) and subsequent LC/MS-MS analyses of product metabolites. The expansion of the applicability domain of the CYP induction assay to industrial and pesticidal chemicals, including MDCs, will allow us to define the optimal use of this test method within approaches for testing strategies for metabolic disruption.

\section{Steatosis}

We will develop in vitro models of both steatosis (i.e., fat accumulation) and IR in HPR116 cells in the first three to four years of GOLIATH. Numerous investigations have been performed in HepaRG cells to study xenobiotic-induced toxicity and related mechanisms [42,52-54]. More specifically, this cellular model has been used to study steatosis induced by different drugs known to be steatogenic in humans, including amiodarone, tamoxifen, tetracycline, and valproic acid [55-57]. Furthermore, HepaRG cells are a relevant model to investigate different mechanisms leading to steatosis including inhibition of mitochondrial fatty acid oxidation and activation of de novo lipogenesis $[55,57,58]$. However, so far, we are aware of only two studies in HepaRG cells reporting the steatotic effect of BPA [18] and TBT [59]. In our previous work on BPA, steatogenic effects were demonstrated for a concentration as low as $2 \mathrm{nM}$, in proliferating and early differentiating HepaRG cells, allowing to mimic a putative perinatal exposure scenario [18]. However, the steatogenic effect of BPA in fully differentiated HepaRG cells has not yet been assessed. Studies on potential steatotic effects of other chemicals in the initial set of GOLIATH (e.g., PFOA, TPP, pp'-DDE, and TCS) have not yet been reported in the scientific literature.

\subsubsection{Endocrine Pancreas}

Pancreatic $\beta$ - and $\alpha$-cells play an essential role in glycemic control through the secretion of insulin and glucagon. T2D is characterized by hypoinsulinemia and hyperglucagonemia with elevated blood glucose levels. Evidence indicates that MDCs alter the functional mass of $\beta$-cells, either increasing or decreasing glucose-stimulated insulin secretion (GSIS) as well as $\beta$ cell division and death $[60,61]$. There are fewer examples of MDCs affecting $\alpha$-cells but it is known that BPA rapidly alters Ca2+ signaling in response to glucose in ex vivo studies [62] and perinatal exposure decreases glucagon levels in offspring [63]. Therefore, in GOLIATH, we will dedicate four to five years to develop and characterize novel cellular testing methods to screen the capacity of MDCs to affect function and survival of pancreatic $\beta$ cells (EndoC- $\beta$ H1 and INS-1E) and $\alpha$ cells ( $\alpha$-TC1-9).

\subsubsection{Muscle}

Skeletal muscle (SM) plays a crucial role in glucose homeostasis. Insulin binding to its receptors on the cell membrane of SM initiates a signaling cascade of phosphorylation eliciting the translocation of vesicles containing glucose transporter 4 (GLUT4) to the plasma membrane initiating glucose transport by facilitated diffusion. Insulin resistance is a primary defect in T2D. Despite evidence suggesting that MDCs induced insulin resistance in SM $[17,64]$, there are studies concerning MDCs action on SM are 
scarce. In GOLIATH we will use the mouse myocyte cell line C2C12 to evaluate insulin signaling upon MDCs exposure, measuring the expression of proteins such as GLUT4 and protein kinase B/AKT.

\subsubsection{Adipocytes}

\section{Adipocyte Commitment and Differentiation}

Within the first two to three years of the project, GOLIATH will focus on developing human-relevant in vitro models to test the effects of MDCs on the differentiation of white, beige/brite, and brown adipocytes. To date, most studies that focused on MDCs and enhanced adipocyte formation have utilized the murine 3T3-L1 pre-adipocyte cell line. With respect to the initial GOLIATH chemical selection, in 3T3-L1 cells, the following MDCs have tested positive for stimulating adipocyte differentiation at concentrations indicated in Table 1: BPA $(10 \mathrm{nM}-100 \mu \mathrm{M})$ [65-70], TBT

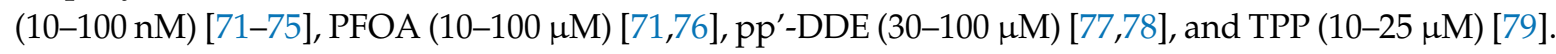
In contrast, less research has been performed on more relevant human models. As the murine 3T3-L1 cell line is already committed to the adipocyte lineage, it provides limited information compared to multipotent human mesenchymal stem cells (hMSCs). As hMSCs remain multi-potent, they can be programmed to differentiate into a variety of cell types, including white, beige/brite, and brown adipocytes. In GOLIATH, we will use commercially available hMSCs to evaluate the effects of MDCs for their ability to: (1) differentiate MSCs into adipocytes (standard adipogenesis assay); (2) commit MSCs to the adipocyte lineage; (3) interfere with (or promote) generation of thermogenic beige/brite adipocytes. The commitment [80] and beiging [81] assays have been applied successfully in mouse bone marrow-derived MSCs following exposure to TBT and RXR activators and will be adapted in GOLIATH to the human model. The standard adipogenesis assay with hMSCs has been previously tested, showing an increase in adipogenesis with TBT $(50 \mathrm{nM})$ [82] and PFOA $(1 \mathrm{nM}$ to $1 \mu \mathrm{M})$ [83]. TCS showed inhibition in adipogenesis $(1.25$ and $2.5 \mu \mathrm{M})$ [84], whereas BPA showed no effects up to $1 \mu \mathrm{M}$ [85]. No literature is available on the adipogenic capacity of $\mathrm{p}, \mathrm{p}^{\prime}$-DDE and TPP in hMSCs.

\section{Insulin Resistance}

In addition to developing methods to test adipocyte differentiation, we will develop methods for determining insulin resistance in adipocytes, to be completed by year 3. To our knowledge, there have been no reports on inducing insulin resistance in adipocytes differentiated from human mesenchymal stem cells. However, insulin resistance-like changes in adipocytes have so far been characterized by murine preadipocyte cells, 3T3-L1. Lo et al. [86] have described the effects of different insulin resistance inducing conditions, such as treatment with $\mathrm{TNF} \alpha$, dexamethasone, high insulin, and hypoxia in 3T3-L1 adipocytes, and compared them with primary murine adipocytes. The effects of MDCs on glucose consumption and insulin sensitivity of 3T3-L1 adipocytes are summarized in Table 2. Some MDCs have been shown to affect basal and insulin-stimulated glucose uptake, GLUT4, and adiponectin expression, as well as that of proinflammatory cytokines (Table 2). In GOLIATH we will use 3T3-L1 adipocytes and hMSCs differentiated into adipocytes to systematically analyze the effects of MDCs on glucose consumption and insulin sensitivity.

Table 2. Effects of MDCs on glucose consumption and insulin sensitivity in in vitro adipocyte models.

\begin{tabular}{|c|c|c|c|c|}
\hline Chemical & Cell Type & Effects & $\begin{array}{c}\text { Concentrations } \\
\text { at Which Effects Observed }\end{array}$ & References \\
\hline BPA & $\begin{array}{l}\text { 3T3-L1 } \\
\text { adipocytes }\end{array}$ & $\begin{array}{ll}\text { - } & \text { Induction of proinflammatory cytokines } \\
\text { - } & \text { Increased basal glucose consumption and } \\
\text { reduced insulin sensitivity }\end{array}$ & $1 \& 100 \mathrm{nM}$ & {$[87,88]$} \\
\hline BPA & $\begin{array}{l}\text { 3T3-F442A } \\
\text { adipocytes }\end{array}$ & $\begin{array}{ll}\text { - } & \text { Increased basal and insulin-stimulated } \\
\text { glucose uptake } \\
\text { - Increased GLUT4 expression }\end{array}$ & $\begin{array}{c}100 \mu \mathrm{M} \\
1 \& 100 \mu \mathrm{M}\end{array}$ & [89] \\
\hline
\end{tabular}


Table 2. Cont.

\begin{tabular}{|c|c|c|c|c|}
\hline Chemical & Cell Type & Effects & $\begin{array}{c}\text { Concentrations } \\
\text { at Which Effects Observed }\end{array}$ & References \\
\hline ТВT & $\begin{array}{l}\text { Differentiating } \\
\text { 3T3-L1 adipocytes }\end{array}$ & $\begin{array}{l}\text { - } \quad \begin{array}{l}\text { Increased basal and insulin-stimulated } \\
\text { glucose uptake }\end{array} \\
\text { - } \quad \text { No effect on GLUT4 mRNA expression }\end{array}$ & $50 \mathrm{nM}$ & [90] \\
\hline TBT & $\begin{array}{l}\text { Differentiating } \\
\text { mMSC adipocytes }\end{array}$ & $\begin{array}{l}\text { - } \quad \text { Decreased adiponectin expression } \\
\text { - } \quad \text { No effect on basal or insulin-stimulated } \\
\text { glucose uptake, and pAkt }\end{array}$ & $100 \mathrm{nM}$ & [81] \\
\hline PFOA & 3T3-L1 adipocytes & - $\quad$ Increased GLUT4 mRNA expression & $200 \mu \mathrm{M}$ & [91] \\
\hline ppDDE & $\begin{array}{c}\text { 3T3-L1 } \\
\text { adipocytes }\end{array}$ & $\begin{array}{ll}\text { - } & \text { Increased adiponectin } \\
\text { - } & \text { No effect on glucose uptake }\end{array}$ & $2 \& 20 \mu \mathrm{M}$ & {$[92,93]$} \\
\hline TPP & 3T3-L1 adipocytes & $\begin{array}{ll}\text { - } & \text { Increased basal glucose uptake } \\
\text { - } & \text { Increased insulin-stimulated glucose } \\
& \text { uptake over long time }\end{array}$ & $\begin{array}{c}0.1-50 \mu \mathrm{M} \\
50 \mu \mathrm{M}\end{array}$ & [79] \\
\hline
\end{tabular}

\subsection{Methods and Approaches to Determine Adverse Outcomes}

GOLIATH will determine the relevance of MDC exposure at the organism level by translating the impact of MDCs on metabolic function in vitro to the organism level, using zebrafish models, existing data from rodent studies, and studies in human cohorts.

\subsubsection{Zebrafish}

A novel in vivo alternative test method to measure metabolic disruption in zebrafish will be developed within the first two years of the project. This test will be an extension of a recently developed method to measure the effects of MDCs on adipogenesis [94] and will use commercially available transgenic zebrafish lines that produce fluorescent pancreatic beta cells and measure effects on pancreas and liver function in addition to adipocyte size and number.

\subsubsection{Rodent Studies}

GOLIATH will examine existing data generated from animal studies performed with the selected MDCs, and utilize this information to propose relevant tissues and endpoints where the current in vivo battery of test guidelines could be augmented. Note that though no new in vivo studies will be conducted within this project, partners within the GOLIATH project will team up with other partners within and outside the EURION cluster who are performing rodent studies to enable translational and cross-species comparative analyses.

\subsubsection{Epidemiological Studies}

Within the framework of GOLIATH, we will explore epidemiologic associations in the "Flemish Environment and Health Studies" that have been running since 2002 (FLEHS, http://www.milieuen-gezondheid.be/) [95-102] and in the "Prevention and Incidence of Asthma and Mite Allergy" cohort study (PIAMA, https://piama.iras.uu.nl/english/) that has been running since 1996 [103,104]. Both cohort studies contain a detailed characterization of lifestyle and environmental exposures as well as information on metabolically relevant molecular and physical outcome parameters at multiple ages in childhood and adolescence. As documented in Table S2, exposure data on p, p'-DDE, PFOA, BPA, and TCS are available for different age groups within FLEHS. New PFOA data from sampled adolescents, is expected to become available within the coming year, as part of the HBM4EU project [105]. The PIAMA cohort will be enriched with untargeted high-resolution mass spectrometry data (exposome scan) to screen and quantify the MDCs and hundreds of other environmental chemicals in addition to endogenous metabolites [106]. We will investigate changes in anthropometric measures (BMI, waist circumference, waist-to-height ratio), concentrations of lipids (HDL-cholesterol, triglycerides), levels of leptin and insulin, and changes in -omics readouts in relation to the concentrations of the chemicals. 
The possible mediating effects of the molecular markers and pathways in the exposure-outcome associations will be explored. Findings will be compared with data collected from cellular, zebrafish, and (existing) in vivo models. Vice versa, putative predictive markers for screening of chemicals for metabolic effects identified within GOLIATH cellular, zebrafish and existing data from in vivo models will be examined in a subset of samples from the cohorts to confirm their human relevance and potential cross-species utility as biomarkers that could be used as part of the augmentation of in vivo test guidelines.

\section{Approaches to Determine Endocrine Mode of Action}

GOLIATH will provide critical information on the endocrine mode of action of chemicals by network modeling and multi-omic approaches. Using multi-omic (transcriptomics, metabolomics, and lipidomics) data from the in vitro models outlined above, metabolic MoAs will be defined as metabolic sub-networks (sets of potentially modulated metabolic reactions) by which MDCs exert metabolic disruption. Sub-network searches will be achieved using computational models of human genome-scale metabolic networks [107] and omics data obtained in cellular studies. The first step will consist in precising the endogenous metabolism of each in vitro model [108]. Then sub-networks will be extracted based on metabolomics and lipidomics data using network algorithms [109]. Resulting sub-networks will be stored in a newly created database (alongside the international repositories for each omic data, e.g., MetaboLights [110] for metabolomic data, ArrayExpress [111] for transcriptomics) and an online visual and interactive web interface will be developed to access these metabolic MoAs and to allow scientists to input their data to perform similar computations. This open platform will be built as an extension of the MetExplore [112] web server developed within the consortium.

\section{From Individual Assays to AOPs and an Integrated Approach to Testing and Assessment of MDCs}

Once standardized and optimized, in vitro test methods developed in GOLIATH will be defined and documented in a harmonized manner to facilitate a comparative assessment of the quality of data produced, and the potential utility in regulatory applications. Based on this information as well as mechanistic, strategic, and intellectual property considerations, sufficiently mature test methods will be prioritized for pre-validation, which will focus on test method transferability, reproducibility between laboratories, optimization of the protocol and preliminary predictivity. These activities will prepare the test methods for potential regulatory uptake. To facilitate this process, each test method will also be aligned with a network of relevant AOPs [113] that will be developed to synthesize the existing knowledge concerning the cascade of causally related key events that link the perturbation of specific molecular targets to the human adverse health outcomes considered within this project. These AOPs will provide a weight-of-evidence-based framework to support the selection of appropriate in vitro assays for the IATA, which will address the critical key events and key event relationships identified for metabolic disruption.

AOPs will also inform the development of an IATA for hazard identification, hazard characterization, and potential risk assessment of MDCs. The IATA will integrate and weigh all relevant evidence to inform regulatory decision-making regarding potential hazard and/or risk of MDCs. OECD IATA guidance will be utilized [114], and lessons learned from IATA projects in progress (e.g., Jacobs et al. [115]) will be applied. The IATA will be tested with selected chemicals to include them as part of the OECD case studies reporting cycle output. The objective of the IATA Case Studies Project is to increase experience with the use of IATA by developing case studies, which constitute examples of predictions that are fit for regulatory use. By putting forward these case studies, GOLIATH will actively contribute to the common understanding of using novel methodologies and the generation of considerations/guidance stemming from these case studies [116]. This work will also help to identify areas for developing further guidance on IATA and will be integral to the recommendations to be made to the relevant OECD and European Commission expert groups, regulators and other stakeholders, regarding the selection of appropriate in vitro assays for the future design of a Metabolic Disruption 
IATA. Uncertainty analysis approaches will be utilized to ensure that uncertainties are identified and transparently documented. In addition, we will identify how the GOLIATH (pre)validated tests can be integrated into the OECD Guidance Document 150, and the European Union EFSA and ECHA Guidance for the identification of endocrine disruptors in the context of Regulations (EU) No 528/2012 and (EC) No 1107/2009 [117].

With a consortium comprised of world-leading experts, GOLIATH will be pivotal in the development of an internationally harmonized strategy for testing and assessing MDCs, with the ultimate aim of protecting human health, slowing the worldwide rise in metabolic disorders that have reached "Goliathan" proportions.

Supplementary Materials: Supplementary materials can be found at http://www.mdpi.com/1422-0067/21/10/ 3480/s1.

Author Contributions: Author Contributions: J.L. wrote the abstract, Sections 1, 3.3.1 and 3.3.2, and reviewed and revised the manuscript. J.L. and A.N. wrote Section 2. P.L.A. and W.B. contributed to Section 3.1.1. Section 3.1.2. was written by P.B. and Section 3.1.3 by S.C. Section 3.2.1 was written by P.B., C.C., D.Z. and B.F. Sections 3.2.2 and 3.2.3 was written by A.N. Section 3.2.4 was written by B.B., V.M.K., S.E. and J.H.K. S.R. wrote Section 3.3.3. F.J. and J.L.G. wrote Section 4. Section 5 was written by M.J., L.M.-C., S.H., and C.B. J.H.K., A.N. and J.L. created the figures, while S.R. and P.L.A. created the supplementary tables. All authors have read and agreed to the published version of the manuscript.

Funding: This project has received funding from the European Union's Horizon 2020 research and innovation program under grant agreement GOLIATH No. 825489.

Acknowledgments: All partners acknowledge the contribution of their institutes for additional financial support. We would also like to acknowledge the following additional members of the GOLIATH consortium: Utrecht University, The Netherlands: Anran Cai, Marjo den Broeder, Virissa Lenters, Roel Vermeulen; INRAE France: Sandrine Bruel, Nicolas Cabaton, Anne Hillenweck, Louisa Mediouni, Elodie Person, Nathalie Poupin, Clément Frainay, Maxime Delmas; INSERM France: Anne Corlu, Vanessa Delfosse, Clementine Garoche, Marina Grimaldi, Jakub Gruszczyk, Julie Massart, Jean-Luc Pons, Lucia Toporova, Gilles Labesse; Karolinska Institutet, Sweden: Astrud Tuck; Universitas Miguel Hernandez, Spain: Reinaldo Sousa dos Santos; ANSES, France: Christophe Rousselle; VITO, Belgium: Eva Govarts; Greet Schoeters; Brunel University London, UK: Andreas Kortenkamp; University of Cambridge, UK: Susana Palma; University of California, Irvine, USA: Angelica Amorim Amato, Xiaomin Ren; Biopredic International, France: Ruoya Li; Umeå University, Sweden: Maria Sapounidou (UMU).

Conflicts of Interest: The authors declare no conflict of interest.

\section{References}

1. WHO Diabetes-Data and Statistics. Available online: http://www.euro.who.int/en/health-topics/ noncommunicable-diseases/diabetes/data-and-statistics (accessed on 25 February 2020).

2. Younossi, Z.M.; Blissett, D.; Blissett, R.; Henry, L.; Stepanova, M.; Younossi, Y.; Racila, A.; Hunt, S.; Beckerman, R. The economic and clinical burden of nonalcoholic fatty liver disease in the United States and Europe. Hepatology 2016, 64, 1577-1586. [CrossRef]

3. Franks, P.W.; McCarthy, M.I. Exposing the exposures responsible for type 2 diabetes and obesity. Science 2016, 354, 69-73. [CrossRef] [PubMed]

4. Heindel, J.J.; Blumberg, B.; Cave, M.; Machtinger, R.; Mantovani, A.; Mendez, M.A.; Nadal, Á.; Palanza, P.; Panzica, G.; Sargis, R.; et al. Metabolism disrupting chemicals and metabolic disorders. Reprod. Toxicol. 2016, 68, 3-33. [CrossRef] [PubMed]

5. European Commission Endocrine Disruptors. Available online: https://ec.europa.eu/environment/chemicals/ endocrine/documents/index_en.htm (accessed on 25 February 2020).

6. EC. European Commission COUNCIL REGULATION (EC) No 440/2008. Off. J. Eur. Union 2008, OJ L 142, $1-739$.

7. OECD. OECD Work on Endocrine Disrupting Chemicals. Available online: https://www.oecd.org/env/ehs/ testing/oecdworkrelatedtoendocrinedisrupters.htm (accessed on 25 February 2020).

8. Jacobs, M.; Janssens, W.; Bernauer, U.; Brandon, E.; Coecke, S.; Combes, R.; Edwards, P.; Freidig, A.; Freyberger, A.; Kolanczyk, R.; et al. The Use of Metabolising Systems for In Vitro Testing of Endocrine Disruptors. Curr. Drug Metab. 2008, 9, 796-826. [CrossRef] [PubMed]

9. Jacobs, M. In vitro metabolism and bioavailability tests for endocrine active substances: What is needed next for regulatory purposes? ALTEX 2013, 30, 331-351. [CrossRef] 
10. Bopp, S.; Nepelska, M.; Halder, M.; Munn, S. Expert survey on identification of gaps in available test methods for evaluation of endocrine disruptors. JRC Tech. Rep. 2017. [CrossRef]

11. OECD. Detailed Review Paper on the State of the Science on Novel In Vitro and In Vivo Screening and Testing Methods and Endpoints for Evaluating Endocrine Disruptors; OECD Series on Testing and Assessment; OECD: Paris, France, 2014; ISBN 9789264221352.

12. FAIR. Available online: https://www.go-fair.org/ (accessed on 30 March 2020).

13. European Association for the Study of the Liver (EASL). EASL-EASD-EASO Clinical Practice Guidelines for the management of non-alcoholic fatty liver disease. Diabetologia 2016, 59, 1121-1140. [CrossRef]

14. Gore, A.C.; Chappell, V.A.; Fenton, S.E.; A Flaws, J.; Nadal, Á.; Prins, G.S.; Toppari, J.; Zoeller, R.T. EDC-2: The Endocrine Society's Second Scientific Statement on Endocrine-Disrupting Chemicals. Endocr. Rev. 2015, 36, E1-E150. [CrossRef]

15. Nadal, Á.; Quesada, I.; Tudurí, E.; Nogueiras, R.; Alonso-Magdalena, P. Endocrine-disrupting chemicals and the regulation of energy balance. Nat. Rev. Endocrinol. 2017, 13, 536-546. [CrossRef]

16. Cano-Sancho, G.; Salmon, A.G.; La Merrill, M.A. Association between Exposure to p,p'-DDT and Its Metabolite p,p '-DDE with Obesity: Integrated Systematic Review and Meta-Analysis. Environ. Health Perspect. 2017, 125, 096002. [CrossRef] [PubMed]

17. Batista, T.; Alonso-Magdalena, P.; Vieira, E.; Amaral, M.E.C.D.; Cederroth, C.R.; Nef, S.; Quesada, I.; Carneiro, E.M.; Nadal, Á. Short-Term Treatment with Bisphenol-A Leads to Metabolic Abnormalities in Adult Male Mice. PLoS ONE 2012, 7, e33814. [CrossRef] [PubMed]

18. Bucher, S.; Jalili, P.; Le Guillou, D.; Begriche, K.; Rondel, K.; Martinais, S.; Zalko, D.; Corlu, A.; Robin, M.-A.; Fromenty, B. Bisphenol a induces steatosis in HepaRG cells using a model of perinatal exposure. Environ. Toxicol. 2016, 32, 1024-1036. [CrossRef] [PubMed]

19. Wassenaar, P.; Trasande, L.; Legler, J. Systematic Review and Meta-Analysis of Early-Life Exposure to Bisphenol A and Obesity-Related Outcomes in Rodents. Environ. Health Perspect. 2017, 125, 106001. [CrossRef]

20. OECD The QSAR Toolbox. Available online: https://www.oecd.org/chemicalsafety/risk-assessment/oecdqsar-toolbox.htm (accessed on 10 October 2019).

21. OECD. Guidance Document on the Validation of (Quantitative) Structure-Activity Relationship [(Q)SAR] Models; OECD Series on Testing and Assessment; OECD: Paris, France, 2014; ISBN 9789264085442.

22. Schneider, M.; Pons, J.-L.; Labesse, G.; Bourguet, W. In Silico Predictions of Endocrine Disruptors Properties. Endocrinology 2019, 160, 2709-2716. [CrossRef]

23. Punt, A.; Aartse, A.; Bovee, T.F.H.; Gerssen, A.; Van Leeuwen, S.P.J.; Hoogenboom, R.; Peijnenburg, A.A.C.M. Quantitative in vitro-to-in vivo extrapolation (QIVIVE) of estrogenic and anti-androgenic potencies of BPA and BADGE analogues. Arch. Toxicol. 2019, 93, 1941-1953. [CrossRef]

24. Leonard, J.A.; Tan, Y.-M.; Gilbert, M.; Isaacs, K.; El-Masri, H. Estimating Margin of Exposure to Thyroid Peroxidase Inhibitors Using High-Throughput in vitro Data, High-Throughput Exposure Modeling, and Physiologically Based Pharmacokinetic/Pharmacodynamic Modeling. Toxicol. Sci. 2016, 151, 57-70. [CrossRef]

25. Kato, H.; Yamaotsu, N.; Iwazaki, N.; Okamura, S.; Kume, T.; Hirono, S. Precise prediction of activators for the human constitutive androstane receptor using structure-based three-dimensional quantitative structure-activity relationship methods. Drug Metab. Pharmacokinet. 2017, 32, 179-188. [CrossRef]

26. Chen, Y.; Yang, H.; Wu, Z.; Liu, G.; Tang, Y.; Li, W. Prediction of Farnesoid X Receptor Disruptors with Machine Learning Methods. Chem. Res. Toxicol. 2018, 31, 1128-1137. [CrossRef]

27. Al Sharif, M.; Tsakovska, I.; Pajeva, I.; Alov, P.; Fioravanzo, E.; Bassan, A.; Kovarich, S.; Yang, C.; Mostrag-Szlichtyng, A.; Vitcheva, V.; et al. The application of molecular modelling in the safety assessment of chemicals: A case study on ligand-dependent PPAR $\gamma$ dysregulation. Toxicology 2017, 392, 140-154. [CrossRef]

28. Yin, C.; Yang, X.; Wei, M.; Liu, H. Predictive models for identifying the binding activity of structurally diverse chemicals to human pregnane X receptor. Environ. Sci. Pollut. Res. 2017, 24, 20063-20071. [CrossRef] [PubMed]

29. Schneider, M.; Pons, J.-L.; Bourguet, W.; Labesse, G. Towards accurate high-throughput ligand affinity prediction by exploiting structural ensembles, docking metrics and ligand similarity. Bioinformatics 2019, 36, 160-168. [CrossRef] [PubMed]

30. Grimaldi, M.; Boulahtouf, A.; Delfosse, V.; Thouënnon, E.; Bourguet, W.; Balaguer, P. Reporter Cell Lines for the Characterization of the Interactions between Human Nuclear Receptors and Endocrine Disruptors. Front. Endocrinol. 2015, 6, 62. [CrossRef] [PubMed] 
31. Grimaldi, M.; Boulahtouf, A.; Toporova, L.; Balaguer, P. Functional profiling of bisphenols for nuclear receptors. Toxicology 2019, 420, 39-45. [CrossRef] [PubMed]

32. Riu, A.; Grimaldi, M.; Le Maire, A.; Bey, G.; Phillips, K.; Boulahtouf, A.; Perdu, E.; Zalko, D.; Bourguet, W.; Balaguer, P. Peroxisome Proliferator-Activated Receptor $\gamma$ Is a Target for Halogenated Analogs of Bisphenol A. Environ. Health Perspect. 2011, 119, 1227-1232. [CrossRef] [PubMed]

33. Del Amor, A.M.C.; Freitas, S.; Urbatzka, R.; Fresnedo, O.; Cristobal, S. Application of Bioactive Thermal Proteome Profiling to Decipher the Mechanism of Action of the Lipid Lowering 132-Hydroxy-pheophytin Isolated from a Marine Cyanobacteria. Mar. Drugs 2019, 17, 371. [CrossRef]

34. Molina, D.M.; Jafari, R.; Chen, D.; Seki, T.; Larsson, A.; Dan, C.; Sreekumar, L.; Cao, Y.; Nordlund, P. Monitoring Drug Target Engagement in Cells and Tissues Using the Cellular Thermal Shift Assay. Science 2013, 341, 84-87. [CrossRef]

35. Savitski, M.M.; Reinhard, F.B.M.; Franken, H.; Werner, T.; Savitski, M.F.; Eberhard, D.; Molina, D.M.; Jafari, R.; Dovega, R.B.; Klaeger, S.; et al. Tracking cancer drugs in living cells by thermal profiling of the proteome. Science 2014, 346, 1255784. [CrossRef]

36. Franken, H.; Mathieson, T.; Childs, D.; A Sweetman, G.M.; Werner, T.; Tögel, I.; Doce, C.; Gade, S.; Bantscheff, M.; Drewes, G.; et al. Thermal proteome profiling for unbiased identification of direct and indirect drug targets using multiplexed quantitative mass spectrometry. Nat. Protoc. 2015, 10, 1567-1593. [CrossRef]

37. Becher, I.; Werner, T.; Doce, C.; Zaal, E.A.; Tögel, I.; Khan, C.; Rueger, A.; Muelbaier, M.; Salzer, E.; Berkers, C.R.; et al. Thermal profiling reveals phenylalanine hydroxylase as an off-target of panobinostat. Nat. Methods 2016, 12, 908-910. [CrossRef]

38. Azimi, A.; Caramuta, S.; Seashore-Ludlow, B.; Boström, J.; Robinson, J.L.; Edfors, F.; Tuominen, R.; Kemper, K.; Krijgsman, O.; Peeper, D.S.; et al. Targeting CDK 2 overcomes melanoma resistance against BRAF and Hsp90 inhibitors. Mol. Syst. Boil. 2018, 14, e7858. [CrossRef] [PubMed]

39. Türkowsky, D.; Lohmann, P.; Mühlenbrink, M.; Schubert, T.; Adrian, L.; Goris, T.; Jehmlich, N.; Von Bergen, M. Thermal proteome profiling allows quantitative assessment of interactions between tetrachloroethene reductive dehalogenase and trichloroethene. J. Proteom. 2019, 192, 10-17. [CrossRef] [PubMed]

40. Gripon, P.; Rumin, S.; Urban, S.; Le Seyec, J.; Glaise, D.; Cannie, I.; Guyomard, C.; Lucas, J.; Trepo, C.; Guguen-Guillouzo, C. Nonlinear partial differential equations and applications: Infection of a human hepatoma cell line by hepatitis B virus. Proc. Natl. Acad. Sci. USA 2002, 99, 15655-15660. [CrossRef] [PubMed]

41. Guillouzo, A.; Corlu, A.; Aninat, C.; Glaise, D.; Morel, F.; Guguen-Guillouzo, C. The human hepatoma HepaRG cells: A highly differentiated model for studies of liver metabolism and toxicity of xenobiotics. Chem. Interact. 2007, 168, 66-73. [CrossRef]

42. Andersson, T.B.; Kanebratt, K.P.; Kenna, G. The HepaRG cell line: A unique in vitro tool for understanding drug metabolism and toxicology in human. Expert Opin. Drug Metab. Toxicol. 2012, 8, 909-920. [CrossRef]

43. Aninat, C.; Piton, A.; Glaise, D.; Le Charpentier, T.; Langouët, S.; Morel, F.; Guguen-Guillouzo, C.; Guillouzo, A. Expression of cytochromes P450, conjugating enzymes and nuclear receptors in human hepatoma HepaRG cells. Drug Metab. Dispos. 2005, 34, 75-83. [CrossRef]

44. Rogue, A.; Lambert, C.; Josse, R.; Antherieu, S.; Spire, C.; Claude, N.; Guillouzo, A. Comparative Gene Expression Profiles Induced by PPAR $\gamma$ and PPAR $\alpha / \gamma$ Agonists in Human Hepatocytes. PLoS ONE 2011, 6, e18816. [CrossRef]

45. Peyta, L.; Jarnouen, K.; Pinault, M.; Guimaraes, C.; De Barros, J.-P.P.; Chevalier, S.; Dumas, J.-F.; Maillot, F.; Hatch, G.M.; Loyer, P.; et al. Reduced cardiolipin content decreases respiratory chain capacities and increases ATP synthesis yield in the human HepaRG cells. Biochim. Biophys. Acta (BBA) Gen. Subj. 2016, 1857, 443-453. [CrossRef]

46. Porceddu, P.; Buron, N.; Rustin, P.; Fromenty, B.; Borgne-Sanchez, A. In Vitro Assessment of Mitochondrial Toxicity to Predict Drug-Induced Liver Injury. In Methods in Molecular Biology; Springer Science and Business Media LLC: New York, NY, USA, 2018; pp. 283-300.

47. Tascher, G.; Burban, A.; Camus, S.; Plumel, M.; Chanon, S.; Le Guevel, R.; Shevchenko, V.; Van Dorsselaer, A.; Lefai, E.; Guguen-Guillouzo, C.; et al. In-Depth Proteome Analysis Highlights HepaRG Cells as a Versatile Cell System Surrogate for Primary Human Hepatocytes. Cells 2019, 8, 192. [CrossRef]

48. Waxman, D.J.; Lapenson, D.P.; Aoyama, T.; Gelboin, H.V.; Gonzalez, F.J.; Korzekwa, K. Steroid hormone hydroxylase specificities of eleven cDNA-expressed human cytochrome P450s. Arch. Biochem. Biophys. 1991, 290, 160-166. [CrossRef] 
49. EURL ECVAM. Multi-Study Validation Trial for Cytochrome P450 Induction Providing a Reliable Human Metabolically Competent Standard Model or Method Using the Human Cryopreserved Primary Hepatocytes and the Human Cryopreserved HepaRGßCell Line; EURL ECVAM: Ispra, Italy, 2014.

50. Bernasconi, C.; Pelkonen, O.; Andersson, T.B.; Strickland, J.; Wilk-Zasadna, I.; Asturiol, D.; Cole, T.; Liska, R.; Worth, A.; Müller-Vieira, U.; et al. Validation of in vitro methods for human cytochrome P450 enzyme induction: Outcome of a multi-laboratory study. Toxicol. Vitr. 2019, 60, 212-228. [CrossRef]

51. OECD Determination of Cytochrome 450 (CYP) Enzyme Activity Induction Using Differentiated Human Hepatic Cells. Available online: http://www.oecd.org/chemicalsafety/testing/Draft_TG_CYP_induction_for_ 2nd_WNT_review.pdf (accessed on 25 February 2020).

52. Le Guillou, D.; Bucher, S.; Begriche, K.; Hoët, D.; Lombes, A.; Labbe, G.; Fromenty, B. Drug-Induced Alterations of Mitochondrial DNA Homeostasis in Steatotic and Nonsteatotic HepaRG Cells. J. Pharmacol. Exp. Ther. 2018, 365, 711-726. [CrossRef] [PubMed]

53. Mueller, S.O.; Guillouzo, A.; Hewitt, P.G.; Richert, L. Drug biokinetic and toxicity assessments in rat and human primary hepatocytes and HepaRG cells within the EU-funded Predict-IV project. Toxicol. Vitr. 2015, 30, 19-26. [CrossRef] [PubMed]

54. Bucher, S.; Le Guillou, D.; Allard, J.; Pinon, G.; Begriche, K.; Tête, A.; Sergent, O.; Lagadic-Gossmann, M.; Fromenty, B. Possible Involvement of Mitochondrial Dysfunction and Oxidative Stress in a Cellular Model of NAFLD Progression Induced by Benzo[a]pyrene/Ethanol CoExposure. Oxidative Med. Cell. Longev. 2018, 2018, 1-18. [CrossRef] [PubMed]

55. Antherieu, S.; Rogue, A.; Fromenty, B.; Guillouzo, A.; Robin, M.-A. Induction of vesicular steatosis by amiodarone and tetracycline is associated with up-regulation of lipogenic genes in heparg cells. Hepatology 2011, 53, 1895-1905. [CrossRef]

56. Tolosa, L.; Gómez-Lechón, M.J.; Jimenez, N.; Hervás, D.; Jover, R.; Donato, M.T. Advantageous use of HepaRG cells for the screening and mechanistic study of drug-induced steatosis. Toxicol. Appl. Pharmacol. 2016, 302, 1-9. [CrossRef]

57. Grünig, D.; Felser, A.; Duthaler, U.; Bouitbir, J.; Krähenbühl, S. Effect of the Catechol-O-Methyltransferase Inhibitors Tolcapone and Entacapone on Fatty Acid Metabolism in HepaRG Cells. Toxicol. Sci. 2018, 164, 477-488. [CrossRef]

58. Allard, J.; Bucher, S.; Ferron, P.-J.; Begriche, K.; Loyer, P.; Fromenty, B. Importance of non-mitochondrial pathways in drug-induced hepatic steatosis: Investigations with 12 steatotic drugs in HepaRG cells. Toxicol. Lett. 2019, 314, S60.

59. Stossi, F.; Dandekar, R.D.; Johnson, H.; LaVere, P.; Foulds, C.E.; Mancini, M.G.; Mancini, M.A. Tributyltin chloride (TBT) induces RXRA down-regulation and lipid accumulation in human liver cells. PLoS ONE 2019, 14, e0224405. [CrossRef]

60. Alonso-Magdalena, P.; Quesada, I.; Nadal, Á. Endocrine disruptors in the etiology of type 2 diabetes mellitus. Nat. Rev. Endocrinol. 2011, 7, 346-353. [CrossRef]

61. Mimoto, M.S.; Nadal, Á.; Sargis, R.M. Polluted Pathways: Mechanisms of Metabolic Disruption by Endocrine Disrupting Chemicals. Curr. Environ. Health Rep. 2017, 4, 208-222. [CrossRef] [PubMed]

62. Alonso-Magdalena, P.; Laribi, O.; Ropero, A.B.; Fuentes, E.; Ripoll, C.; Soria, B.; Nadal, Á. Low Doses of Bisphenol A and Diethylstilbestrol Impair Ca2+ Signals in Pancreatic $\alpha$-Cells through a Nonclassical Membrane Estrogen Receptor within Intact Islets of Langerhans. Environ. Health Perspect. 2005, 113, 969-977. [CrossRef] [PubMed]

63. Van Esterik, J.; Dollé, M.; Lamoree, M.; Van Leeuwen, S.P.J.; Hamers, T.; Legler, J.; Van Der Ven, L.T. Programming of metabolic effects in C57BL/6JxFVB mice by exposure to bisphenol A during gestation and lactation. Toxicology 2014, 321, 40-52. [CrossRef] [PubMed]

64. Davis, A.F.; Thomas, A.A.; Shorter, K.S.; Brown, S.L.; Baumgarner, B.L. Cellular fatty acid level regulates the effect of tolylfluanid on mitochondrial dysfunction and insulin sensitivity in C2C12 skeletal myotubes. Biochem. Biophys. Res. Commun. 2018, 505, 392-398. [CrossRef] [PubMed]

65. Drobna, Z.; Talarovicova, A.; Schrader, H.E.; Fennell, T.R.; Snyder, R.W.; Rissman, E. Bisphenol F has different effects on preadipocytes differentiation and weight gain in adult mice as compared with Bisphenol A and S. Toxicology 2019, 420, 66-72. [CrossRef] [PubMed] 
66. Pomatto, V.; Cottone, E.; Cocci, P.; Mozzicafreddo, M.; Mosconi, G.; Nelson, E.R.; Palermo, F.A.; Bovolin, P. Plasticizers used in food-contact materials affect adipogenesis in 3T3-L1 cells. J. Steroid Biochem. Mol. Boil. 2018, 178, 322-332. [CrossRef]

67. Sargis, R.M.; Johnson, D.N.; Choudhury, R.A.; Brady, M.J. Environmental endocrine disruptors promote adipogenesis in the 3T3-L1 cell line through glucocorticoid receptor activation. Obesity 2009, 18, 1283-1288. [CrossRef]

68. Wada, K.; Sakamoto, H.; Nishikawa, K.; Sakuma, S.; Nakajima, A.; Fujimoto, Y.; Kamisaki, Y. Life style-related diseases of the digestive system: Endocrine disruptors stimulate lipid accumulation in target cells related to metabolic syndrome. J. Pharmacol. Sci. 2007, 105, 133-137. [CrossRef]

69. Taxvig, C.; Dreisig, K.; Boberg, J.; Nellemann, C.; Schelde, A.B.; Pedersen, D.; Boergesen, M.; Mandrup, S.; Vinggaard, A.M. Differential effects of environmental chemicals and food contaminants on adipogenesis, biomarker release and PPAR $\gamma$ activation. Mol. Cell. Endocrinol. 2012, 361, 106-115. [CrossRef]

70. Kassotis, C.; Masse, L.; Kim, S.; Schlezinger, J.; Webster, T.F.; Stapleton, H.M. Characterization of Adipogenic Chemicals in Three Different Cell Culture Systems: Implications for Reproducibility Based on Cell Source and Handling. Sci. Rep. 2017, 7, 42104. [CrossRef]

71. Sales, L.B.; Kamstra, J.H.; Cenijn, P.; Van Rijt, L.; Hamers, T.; Legler, J. Effects of endocrine disrupting chemicals on in vitro global DNA methylation and adipocyte differentiation. Toxicol. Vitr. 2013, 27, 1634-1643. [CrossRef] [PubMed]

72. Lima, L.C.F.; Merlo, E.; Zicker, M.C.; Navia-Pelaez, J.M.; De Oliveira, M.; Capettini, L.D.S.A.; Nogueira, C.R.; Ferreira, A.V.M.; Santos, S.H.S.; Graceli, J.B. Tributyltin impacts in metabolic syndrome development through disruption of angiotensin II receptor signaling pathways in white adipose tissue from adult female rats. Toxicol. Lett. 2018, 299, 21-31. [CrossRef] [PubMed]

73. Bertuloso, B.D.; Podratz, P.L.; Merlo, E.; De Araújo, J.F.; Lima, L.C.F.; De Miguel, E.C.; De Souza, L.N.; Gava, A.L.; De Oliveira, M.; Miranda-Alves, L.; et al. Tributyltin chloride leads to adiposity and impairs metabolic functions in the rat liver and pancreas. Toxicol. Lett. 2015, 235, 45-59. [CrossRef] [PubMed]

74. Grün, F.; Watanabe, H.; Zamanian, Z.; Maeda, L.; Arima, K.; Cubacha, R.; Gardiner, D.M.; Kanno, J.; Iguchi, T.; Blumberg, B. Endocrine-disrupting organotin compounds are potent inducers of adipogenesis in vertebrates. Mol. Endocrinol. 2006, 20, 2141-2155. [CrossRef]

75. Pereira-Fernandes, A.; Demaegdt, H.; Vandermeiren, K.; Hectors, T.L.M.; Jorens, P.G.; Blust, R.; Vanparys, C. Evaluation of a Screening System for Obesogenic Compounds: Screening of Endocrine Disrupting Compounds and Evaluation of the PPAR Dependency of the Effect. PLoS ONE 2013, 8, e77481. [CrossRef]

76. Watkins, A.M.; Wood, C.R.; Lin, M.T.; Abbott, B. The effects of perfluorinated chemicals on adipocyte differentiation in vitro. Mol. Cell. Endocrinol. 2015, 400, 90-101. [CrossRef]

77. Mangum, L.H.; Howell, G.E.; Chambers, J.E. Exposure to p,p'-DDE enhances differentiation of 3T3-L1 preadipocytes in a model of sub-optimal differentiation. Toxicol. Lett. 2015, 238, 65-71. [CrossRef]

78. Kim, J.; Sun, Q.; Yue, Y.; Yoon, K.; Whang, K.-Y.; Clark, J.; Park, Y. 4,4'-Dichlorodiphenyltrichloroethane (DDT) and 4,4'-dichlorodiphenyldichloroethylene (DDE) promote adipogenesis in 3T3-L1 adipocyte cell culture. Pestic. Biochem. Physiol. 2016, 131, 40-45. [CrossRef] [PubMed]

79. Cano-Sancho, G.; Smith, A.; La Merrill, M.A. Triphenyl phosphate enhances adipogenic differentiation, glucose uptake and lipolysis via endocrine and noradrenergic mechanisms. Toxicol. Vitr. 2017, 40, $280-288$. [CrossRef]

80. Shoucri, B.M.; Martinez, E.S.; Abreo, T.J.; Hung, V.; Moosova, Z.; Shioda, T.; Blumberg, B. Retinoid X Receptor Activation Alters the Chromatin Landscape To Commit Mesenchymal Stem Cells to the Adipose Lineage. Endocrinology 2017, 158, 3109-3125. [CrossRef]

81. Shoucri, B.M.; Hung, V.; Chamorro-García, R.; Shioda, T.; Blumberg, B. Retinoid X Receptor Activation During Adipogenesis of Female Mesenchymal Stem Cells Programs a Dysfunctional Adipocyte. Endocrinology 2018, 159, 2863-2883. [CrossRef] [PubMed]

82. Kirchner, S.; Kieu, T.; Chow, C.; Casey, S.; Blumberg, B. Prenatal exposure to the environmental obesogen tributyltin predisposes multipotent stem cells to become adipocytes. Mol. Endocrinol. 2010, 24, 526-539. [CrossRef]

83. Liu, S.; Yang, R.; Yin, N.; Wang, Y.-L.; Faiola, F. Environmental and human relevant PFOS and PFOA doses alter human mesenchymal stem cell self-renewal, adipogenesis and osteogenesis. Ecotoxicol. Environ. Saf. 2019, 169, 564-572. [CrossRef] [PubMed] 
84. Guo, L.-W.; Wu, Q.; Green, B.; Nolen, G.; Shi, L.; Losurdo, J.; Deng, H.; Bauer, S.; Fang, J.-L.; Ning, B. Cytotoxicity and inhibitory effects of low-concentration triclosan on adipogenic differentiation of human mesenchymal stem cells. Toxicol. Appl. Pharmacol. 2012, 262, 117-123. [CrossRef] [PubMed]

85. Chamorro-García, R.; Kirchner, S.; Li, X.; Janesick, A.; Casey, S.C.; Chow, C.; Blumberg, B. Bisphenol A Diglycidyl Ether Induces Adipogenic Differentiation of Multipotent Stromal Stem Cells through a Peroxisome Proliferator-Activated Receptor Gamma-Independent Mechanism. Environ. Health Perspect. 2012, 120, 984-989. [CrossRef]

86. Lo, K.A.; Labadorf, A.; Kennedy, N.J.; Han, M.S.; Yap, Y.S.; Matthews, B.; Xin, X.; Sun, L.; Davis, R.J.; Lodish, H.F.; et al. Analysis of in vitro insulin-resistance models and their physiological relevance to in vivo diet-induced adipose insulin resistance. Cell Rep. 2013, 5, 259-270. [CrossRef]

87. Valentino, R.; D’Esposito, V.; Passaretti, F.; Liotti, A.; Cabaro, S.; Longo, M.; Perruolo, G.; Oriente, F.; Beguinot, F.; Formisano, P. Bisphenol-A Impairs Insulin Action and Up-Regulates Inflammatory Pathways in Human Subcutaneous Adipocytes and 3T3-L1 Cells. PLoS ONE 2013, 8, e82099. [CrossRef]

88. Ariemma, F.; D’Esposito, V.; Liguoro, D.; Oriente, F.; Cabaro, S.; Liotti, A.; Cimmino, I.; Longo, M.; Beguinot, F.; Formisano, P.; et al. Low-Dose Bisphenol-A Impairs Adipogenesis and Generates Dysfunctional 3T3-L1 Adipocytes. PLoS ONE 2016, 11, e0150762. [CrossRef]

89. Sakurai, K.; Kawazuma, M.; Adachi, T.; Harigaya, T.; Saito, Y.; Hashimoto, N.; Mori, C. Bisphenol A affects glucose transport in mouse 3T3-F442A adipocytes. Br. J. Pharmacol. 2004, 141, 209-214. [CrossRef]

90. Regnier, S.M.; El-Hashani, E.; Kamau, W.S.; Zhang, X.; Massad, N.L.; Sargis, R.M. Tributyltin differentially promotes development of a phenotypically distinct adipocyte. Obesity 2015, 23, 1864-1871. [CrossRef]

91. Yamamoto, J.; Yamane, T.; Oishi, Y.; Kobayashi-Hattori, K. Perfluorooctanoic acid binds to peroxisome proliferator-activated receptor? And promotes adipocyte differentiation in 3T3-L1 adipocytes. Biosci. Biotechnol. Biochem. 2014, 79, 636-639. [CrossRef] [PubMed]

92. Howell, G.E.; Meek, E.; Kilic, J.; Mohns, M.; Mulligan, C.; Chambers, J.E. Exposure to p,p'-dichlorodiphenyl dichloroethylene (DDE) induces fasting hyperglycemia without insulin resistance in male $\mathrm{C} 57 \mathrm{BL} / 6 \mathrm{H}$ mice. Toxicology 2014, 320, 6-14. [CrossRef] [PubMed]

93. Howell, G.; Mangum, L. Corrigendum to "Exposure to bioaccumulative organochlorine compounds alters adipogenesis, fatty acid uptake, and adipokine production in NIH3T3-L1 cells" [Toxicol. In Vitro 25(1) 394-402]. Toxicol. Vitr. 2011, 25, 1507. [CrossRef]

94. Broeder, M.D.; Moester, M.J.B.; Kamstra, J.H.; Cenijn, P.; Davidoiu, V.; Kamminga, L.M.; Ariese, F.; De Boer, J.F.; Legler, J. Altered Adipogenesis in Zebrafish Larvae Following High Fat Diet and Chemical Exposure Is Visualised by Stimulated Raman Scattering Microscopy. Int. J. Mol. Sci. 2017, 18, 894. [CrossRef]

95. Schoeters, G.; Govarts, E.; Bruckers, L.; Den Hond, E.; Nelen, V.; De Henauw, S.; Sioen, I.; Nawrot, T.S.; Plusquin, M.; Vriens, A.; et al. Three cycles of human biomonitoring in Flanders - Time trends observed in the Flemish Environment and Health Study. Int. J. Hyg. Environ. Health 2017, 220, 36-45. [CrossRef]

96. De Craemer, S.; Croes, K.; Van Larebeke, N.; De Henauw, S.; Schoeters, G.; Govarts, E.; Loots, I.; Nawrot, T.; Nelen, V.; Hond, E.D.; et al. Metals, hormones and sexual maturation in Flemish adolescents in three cross-sectional studies (2002-2015). Environ. Int. 2017, 102, 190-199. [CrossRef]

97. Baeyens, W.; Vrijens, J.; Gao, Y.; Croes, K.; Schoeters, G.; Den Hond, E.; Sioen, I.; Bruckers, L.; Nawrot, T.; Nelen, V.; et al. Trace metals in blood and urine of newborn/mother pairs, adolescents and adults of the Flemish population (2007-2011). Int. J. Hyg. Environ. Health 2014, 217, 878-890. [CrossRef]

98. Croes, K.; Hond, E.D.; Bruckers, L.; Loots, I.; Morrens, B.; Nelen, V.; Colles, A.; Schoeters, G.; Sioen, I.; Covaci, A.; et al. Monitoring chlorinated persistent organic pollutants in adolescents in Flanders (Belgium): Concentrations, trends and dose-effect relationships (FLEHS II). Environ. Int. 2014, 71, 20-28. [CrossRef]

99. Hond, E.D.; Paulussen, M.; Geens, T.; Bruckers, L.; Baeyens, W.; David, F.; Dumont, E.; Loots, I.; Morrens, B.; De Bellevaux, B.N.; et al. Biomarkers of human exposure to personal care products: Results from the Flemish Environment and Health Study (FLEHS 2007-2011). Sci. Total Environ. 2013, 463, 102-110. [CrossRef]

100. Vrijens, J.; Leermakers, M.; Stalpaert, M.; Schoeters, G.; Hond, E.D.; Bruckers, L.; Colles, A.; Nelen, V.; Mieroop, E.V.D.; Van Larebeke, N.; et al. Trace metal concentrations measured in blood and urine of adolescents in Flanders, Belgium: Reference population and case studies Genk-Zuid and Menen. Int. J. Hyg. Environ. Health 2014, 217, 515-527. [CrossRef] [PubMed] 
101. Koppen, G.; Hond, E.D.; Nelen, V.; Van De Mieroop, E.; Bruckers, L.; Bilau, M.; Keune, H.; Van Larebeke, N.; Covaci, A.; Van De Weghe, H.; et al. Organochlorine and heavy metals in newborns: Results from the Flemish Environment and Health Survey (FLEHS 2002-2006). Environ. Int. 2009, 35, 1015-1022. [CrossRef] [PubMed]

102. Koppen, G.; Covaci, A.; Van Cleuvenbergen, R.; Schepens, P.; Winneke, G.; Nelen, V.; van Larebeke, N.; Vlietinck, R.; Schoeters, G.; Cleuvenbergen, R. Van Persistent organochlorine pollutants in human serum of 50-65 years old women in the Flanders Environmental and Health Study ( FLEHS ). Part 1: Concentrations and regional differences. Chemosphere 2002, 48, 811-825. [CrossRef]

103. Brunekreef, B.; Smit, J.; De Jongste, J.; Neijens, H.; Gerritsen, J.; Postma, D.; Aalberse, R.; Koopman, L.; Kerkhof, M.; Wijga, A.; et al. The Prevention and Incidence of Asthma and Mite Allergy (PIAMA) birth cohort study: Design and first results. Pediatr. Allergy Immunol. 2002, 13, 55-60. [CrossRef]

104. Wijga, A.; Kerkhof, M.; Gehring, U.; De Jongste, J.C.; Postma, D.S.; Aalberse, R.C.; Wolse, A.P.; Koppelman, G.H.; Van Rossem, L.; Oldenwening, M.; et al. Cohort profile: The Prevention and Incidence of Asthma and Mite Allergy (PIAMA) birth cohort. Int. J. Epidemiol. 2013, 43, 527-535. [CrossRef] [PubMed]

105. Ganzleben, C.; Antignac, J.-P.; Barouki, R.; Castano, A.; Fiddicke, U.; Klánová, J.; Lebret, E.; Olea, N.; Sarigiannis, D.; Schoeters, G.R.; et al. Human biomonitoring as a tool to support chemicals regulation in the European Union. Int. J. Hyg. Environ. Health 2017, 220, 94-97. [CrossRef] [PubMed]

106. Vermeulen, R.; Schymanski, E.L.; Barabási, A.-L.; Miller, G. The exposome and health: Where chemistry meets biology. Science 2020, 367, 392-396. [CrossRef] [PubMed]

107. Brunk, E.; Sahoo, S.; Zielinski, D.C.; Altunkaya, A.; Dräger, A.; Mih, N.; Gatto, F.; Nilsson, A.; Gonzalez, G.A.P.; Aurich, M.K.; et al. Recon3D enables a three-dimensional view of gene variation in human metabolism. Nat. Biotechnol. 2018, 36, 272-281. [CrossRef]

108. Poupin, N.; Corlu, A.; Cabaton, N.J.; Dubois-Pot-Schneider, H.; Canlet, C.; Person, E.; Bruel, S.; Frainay, C.; Vinson, F.; Maurier, F.; et al. Large-Scale Modeling Approach Reveals Functional Metabolic Shifts during Hepatic Differentiation. J. Proteome Res. 2018, 18, 204-216. [CrossRef]

109. Frainay, C.; Jourdan, F. Computational methods to identify metabolic sub-networks based on metabolomic profiles. Briefings Bioinform. 2016, 18, 43-56. [CrossRef]

110. Haug, K.; Salek, R.M.; Conesa, P.; Hastings, J.; De Matos, P.; Rijnbeek, M.; Mahendraker, T.; Williams, M.; Neumann, S.; Rocca-Serra, P.; et al. MetaboLights-An open-access general-purpose repository for metabolomics studies and associated meta-data. Nucleic Acids Res. 2012, 41, D781-D786. [CrossRef]

111. Athar, A.; Füllgrabe, A.; George, N.; Iqbal, H.; Huerta, L.; Ali, A.; Snow, C.; A Fonseca, N.; Petryszak, R.; Papatheodorou, I.; et al. ArrayExpress update - from bulk to single-cell expression data. Nucleic Acids Res. 2019, 47, D711-D715. [CrossRef] [PubMed]

112. Cottret, L.; Frainay, C.; Chazalviel, M.; Cabanettes, F.; Gloaguen, Y.; Camenen, E.; Merlet, B.; Heux, S.; Portais, J.-C.; Poupin, N.; et al. MetExplore: Collaborative edition and exploration of metabolic networks. Nucleic Acids Res. 2018, 46, W495-W502. [CrossRef] [PubMed]

113. Knapen, D.; Angrish, M.M.; Fortin, M.C.; Katsiadaki, I.; Leonard, M.; Margiotta-Casaluci, L.; Munn, S.; O'Brien, J.M.; Pollesch, N.; Smith, L.; et al. Adverse outcome pathway networks I: Development and applications. Environ. Toxicol. Chem. 2018, 37, 1723-1733. [CrossRef] [PubMed]

114. OECD. Report on Considerations from Case Studies on Integrated Approaches for Testing and Assessment (IATA) - First Review Cycle (2015); OECD Series on Testing and Assessment; OECD: Paris, France, 2017; ISBN 9789264274815.

115. Jacobs, M. International regulatory needs for development ofan IATA for non-genotoxic carcinogenic chemical substances. ALTEX 2016, 33, 359-392. [CrossRef] [PubMed]

116. OECD Integrated Approaches to Testing and Assessment (IATA). Available online: http://www.oecd.org/ chemicalsafety/risk-assessment/iata-integrated-approaches-to-testing-and-assessment.htm (accessed on 25 February 2020).

117. European Chemical Agency (ECHA) and European Food Safety Authority (EFSA) with the technical support of the Joint Research Centre (JRC); Andersson, N.; Arena, M.; Auteri, D.; Barmaz, S.; Grignard, E.; Kienzler, A.; Lepper, P.; Lostia, A.M.; Munn, S.; et al. Guidance for the identification of endocrine disruptors in the context of Regulations (EU) No 528/2012 and (EC) No 1107/2009. EFSA J. 2018, 16. [CrossRef]

(C) 2020 by the authors. Licensee MDPI, Basel, Switzerland. This article is an open access article distributed under the terms and conditions of the Creative Commons Attribution (CC BY) license (http://creativecommons.org/licenses/by/4.0/). 